\title{
ICP-MS analysis of metal and metalloid concentrations of common microbiological growth media reveals presence of heavy metals
}

\author{
Wenfa $\mathrm{Ng}$ \\ Department of Chemical and Biomolecular Engineering, National University of Singapore, \\ Email: ngwenfa771@ hotmail.com
}

\begin{abstract}
Trace elements such as cobalt and manganese play important roles as cofactors of enzymes, and thus, they collectively impact on biochemistry and cellular metabolism. Hence, it is of importance to gain an understanding of the trace metal and metalloid concentrations of growth medium in order to fully account for the growth performance of the bacterium. But, this aspect of microbial cell cultivation is usually neglected. Advent of instrumented techniques for metals and metalloid analysis such as inductively coupled plasma mass spectrometry (ICP-MS) has significantly facilitated trace element analysis at the parts per billion (ppb) to parts per million (ppm) level in aqueous matrixes free of organic interference. In this work, ICP-MS was utilized as the principal tool for profiling the range of metals and metalloids in different microbiological growth medium ranging from minimal salts medium to complex chemically undefined medium. Growth media examined include: LB Lennox, LB Lennox +2 g/L glucose, LB Lennox (buffered, $89 \mathrm{mM}$ phosphate), LB Lennox (buffered, $89 \mathrm{mM}$ phosphate) $+6 \mathrm{~g} / \mathrm{L}$ glucose, formulated medium $+6 \mathrm{~g} / \mathrm{L}$ glucose, Tryptic Soy Broth, M9 medium, and M9 $+1 \mathrm{~g} / \mathrm{L}$ yeast extract medium. Results reveal detection of elevated concentrations of chromium, copper and cadmium in different versions of LB Lennox and Tryptic Soy Broth. Concentrations of the above heavy metals in the tens of ppm range meant that the growth media could only support the growth of environmental bacteria with some resistance to heavy metal toxicity. On the other hand, no heavy metals were detected in M9 minimal salts medium or a modified version with supplementation of $1 \mathrm{~g} / \mathrm{L}$ yeast extract. This indicated that minimal salts media may have less of a problem with heavy metal contamination compared to chemically undefined microbiological growth media. Collectively, the results highlight the essentiality of conducting a comprehensive profiling experiment for detecting different metals and metalloids at trace levels in microbiological growth medium. Such data would in addition to offering a deeper understanding of some peculiar growth behaviour from some microorganisms, may also help identify contamination issue during manufacture that preclude use of the media in cultivating many laboratory domesticated microorganisms.
\end{abstract}

Keywords: metals and metalloids, elemental composition, inductively coupled plasma mass spectrometry, microbiological growth medium, complex media, minimal salts media,

Subject areas: biochemistry, biotechnology, cell biology, microbiology, biochemical engineering, 


\section{Introduction}

Microbial growth requires carbon, nitrogen, sulphur, hydrogen, oxygen, and phosphorus. But, what is less often noted is the importance of trace elements in microbial growth and function. ${ }^{1,2}$ For example, zinc is an important cofactor for some enzymes., Naturally, the trace element requirement of different microbial species would likely be different, and this may be defined through a survey of the enzymes encoded in the genome of the organism. Besides nutritional roles of trace elements, another important aspect in understanding the elemental composition of microbiological growth medium is for quality control purposes as lapses in manufacturing may introduce unneeded contaminants into the growth medium.

The issue is particularly serious for rich medium. Typically, such media are chemically complex and undefined; thereby, leaving the scientist unable to correlate medium composition with growth behaviour of a microbe should problems of poor growth occur in the experiment. More importantly, components such as yeast extract and tryptone commonly incorporated into rich media carry an undefined elemental composition that serves as variability factors in microbial cell culture, particularly in applications such as cell differentiation studies or where the growth state of the cells are important. Indeed, yeast extract and tryptone both suffer from batch to batch variability, and this element introduces unpredictability to microbial cell culture through differences in amino acids, growth factors, vitamins, and less often noted, trace metal and metalloids compositions. Given the important role played by trace elements in serving as cofactors of enzymes and supporting other critical cellular functions, ${ }^{5}$ types and concentrations of trace elements in microbiological growth medium should be a facet that deserve comprehensive quantification.

Approaches for quantifying elemental compositions of microbiological medium typically revolves around instrumented approaches or those based on chemical reactions followed by calorimetric assays. ${ }^{6,7}$ For trace element analysis, instrumented approaches such as inductively coupled plasma mass spectrometry (ICP-MS) and inductively coupled plasma optical emission spectroscopy (ICP-OES) are suitable and go-to tools. ${ }^{8-10}$ Amongst the two techniques, ICP-MS is the more sensitive approach, and is able to detect, with precision, parts per billion ( $\mathrm{ppb}$ ) concentration of many metals and metalloids in the Periodic table. On the other hand, ICP-OES is a more robust and less maintenance intensive instrument for routine detection of elements in the parts per million ( $\mathrm{ppm}$ ) range in more difficult matrixes.

This work sought to quantify the presence and concentrations of a range of metals and metalloids in common microbiological growth media through ICP-MS analysis. Growth medium considered include, LB Lennox, LB Lennox $+2 \mathrm{~g} / \mathrm{L}$ glucose, LB Lennox (buffered, $89 \mathrm{mM}$ phosphate), LB Lennox (buffered, $89 \mathrm{mM}$ phosphate) $+6 \mathrm{~g} / \mathrm{L}$ glucose, formulated medium +6 g/L glucose, Tryptic Soy Broth, M9 medium, and M9 $+1 \mathrm{~g} / \mathrm{L}$ yeast extract medium. Different growth media were prepared in glass shake flasks, and the contents sterilized at $121{ }^{\circ} \mathrm{C}$ for 20 minutes in an autoclave. Sampling was done after the media have cooled to room temperature. Overall, the experimental protocol developed for this work tried 
to mimic the environmental conditions in the growth media as closely as possible to when it is used in actual settings for microbial cultivation.

\section{Materials and methods}

\subsection{Chemicals and growth medium}

Multi-element calibration standard for calibrating inductively coupled plasma mass spectrometry (ICP-MS) was purchased from Merck. LB medium and Tryptic Soy Broth were purchased from BD and Merck, respectively. The rest of the medium components were purchased from Sigma-Aldrich. Composition of LB Lennox medium is [g/L]: Tryptone, 10.0; Yeast extract, 5.0; $\mathrm{NaCl}$, 5.0. Composition of LB Lennox $+2 \mathrm{~g} / \mathrm{L}$ glucose medium is $[\mathrm{g} / \mathrm{L}]$ : Tryptone, 10.0; Yeast extract, 5.0; NaCl, 5.0; D-Glucose, 2.0. Composition of LB Lennox (buffered, $89 \mathrm{mM}$ phosphate) medium is [g/L]: Tryptone, 10.0; Yeast extract, 5.0; $\mathrm{NaCl}, 5.0$; $\mathrm{K}_{2} \mathrm{HPO}_{4}, 12.54 ; \mathrm{KH}_{2} \mathrm{PO}_{4}, 2.31$. Composition of LB Lennox (buffered, $89 \mathrm{mM}$ phosphate) +6 $\mathrm{g} / \mathrm{L}$ glucose medium is [g/L]: Tryptone, 10.0; Yeast extract, 5.0; $\mathrm{NaCl}, 5.0 ; \mathrm{D}-\mathrm{Glucose}, 6.0$, $\mathrm{K}_{2} \mathrm{HPO}_{4}, 12.54 ; \mathrm{KH}_{2} \mathrm{PO}_{4}, 2.31$. Composition of formulated medium $+6 \mathrm{~g} / \mathrm{L}$ glucose medium is [g/L]: $\mathrm{K}_{2} \mathrm{HPO}_{4}, 12.54 ; \mathrm{KH}_{2} \mathrm{PO}_{4}, 2.31$; D-Glucose, 4.0; $\mathrm{NH}_{4} \mathrm{Cl}, 1.0 ;$ Yeast extract, 12.0; $\mathrm{NaCl}$, 5.0; $\mathrm{MgSO}_{4}, 0.24$; Composition of Tryptic Soy Broth is [g/L]: Peptone from casein 17.0; Peptone from soymeal 3.0; D-Glucose 2.5; $\mathrm{NaCl} 5.0 ; \mathrm{K}_{2} \mathrm{HPO}_{4}, 2.5$. Composition of M9 medium is [g/L]: D-Glucose, 4.0; $\mathrm{NH}_{4} \mathrm{Cl}, 1.0 ; \mathrm{NaH}_{2} \mathrm{PO}_{4}, 3.0 ; \mathrm{Na}_{2} \mathrm{HPO}_{4}, 6.78 ; \mathrm{NaCl}, 0.5$; $\mathrm{MgSO}_{4}, 0.24$. Composition of $\mathrm{M} 9$ minimal medium supplemented with $1 \mathrm{~g} / \mathrm{L}$ yeast extract was [g/L]: D-Glucose, 4.0; $\mathrm{NH}_{4} \mathrm{Cl}, 1.0 ; \mathrm{NaH}_{2} \mathrm{PO}_{4}, 3.0 ; \mathrm{Na}_{2} \mathrm{HPO}_{4}, 6.78 ; \mathrm{NaCl}, 0.5 ; \mathrm{MgSO}_{4}, 0.24$; yeast extract, 1.0 .

\subsection{Growth medium preparation and sterilization}

Different growth media were constituted as is according to manufacturers' instructions or through weighing and dissolving different medium components. The solvent used was deionized water prepared from the combined filtration and ion exchange system with cationic and anionic ion exchange resins. $100 \mathrm{~mL}$ media were prepared in $250 \mathrm{~mL}$ glass shake flask stopped with a cotton plug. After sterilization at $121{ }^{\circ} \mathrm{C}$ for 20 minutes in an autoclave, the prepared media were allowed to cool to room temperature prior to withdrawal of samples using aseptic technique in a Class II Biosafety cabinet on the day of the ICP-MS analysis.

2.3 Sample preparation and inductively coupled plasma mass spectrometry (ICP-MS) analysis

Using aseptic technique, $5 \mathrm{~mL}$ samples were obtained from each type of sterilized growth medium contained in individual shake flasks. Three samples representing three technical replicates were obtained from each type of growth medium in a single flask. Samples were diluted 100 times prior to filtration through a $0.45 \mu \mathrm{m}$ nylon membrane filter prior to ICPMS analysis. After filtration, samples were placed in $20 \mathrm{~mL}$ polyethylene sample bottle. 
Agilent 7500a ICP-MS was calibrated by a calibration series of $0,50 \mathrm{ppb}, 100 \mathrm{ppb}, 500$ ppb, 1000 ppb, 5000 ppb, 10000 ppb calibration standards obtained from diluting a Merck multi-element calibration standard with $18.2 \mathrm{M} \Omega$ ultrapure water. Instrument was operated under hot plasma mode $(1250 \mathrm{~W})$. Fresh calibration standards were used for calibrating the instrument. Detection was attempted for each calibrated element and isotope in each sample.

\section{Results and Discussion}

Table 1: Metals and metalloids concentration in LB Lennox medium

\begin{tabular}{cc} 
Elements & Concentration / ppm \\
\hline${ }^{7} \mathrm{Li}$ & 59.07 \\
${ }^{11} \mathrm{~B}$ & 12.60 \\
${ }^{24} \mathrm{Mg}$ & 197.87 \\
${ }^{27} \mathrm{Al}$ & 6.02 \\
${ }^{43} \mathrm{Ca}$ & 202.87 \\
${ }^{53} \mathrm{Cr}$ & 75.15 \\
${ }^{55} \mathrm{Mn}$ & 1.17 \\
${ }^{56} \mathrm{Fe}$ & 374.00 \\
${ }^{57} \mathrm{Fe}$ & 1331.00 \\
${ }^{59} \mathrm{Co}$ & 0.04 \\
${ }^{60} \mathrm{Ni}$ & 1.77 \\
${ }^{63} \mathrm{Cu}$ & 16.62 \\
${ }^{66} \mathrm{Zn}$ & 0.89 \\
${ }^{69} \mathrm{Zn}$ & 0.00 \\
${ }^{106} \mathrm{Cd}$ & 13.71 \\
${ }^{108} \mathrm{Cd}$ & 0.00 \\
${ }^{111} \mathrm{Cd}$ & 0.00 \\
${ }^{137} \mathrm{Ba}$ & 0.41 \\
${ }^{206} \mathrm{~Pb}$ & 0.00 \\
${ }^{207} \mathrm{~Pb}$ & 0.00 \\
${ }^{208} \mathrm{~Pb}$ & 0.00 \\
${ }^{209} \mathrm{Bi}$ & 1.90 \\
\hline
\end{tabular}

ICP-MS analysis of LB Lennox medium (Table 1) revealed the presence of elevated concentrations of chromium (75.15 ppm), copper (16.62 ppm) and cadmium (13.71 ppm). The data suggested that the heavy metal concentrations in LB Lennox medium may made it unsuitable for the cultivation of many laboratory domesticated bacteria given their sensitivity to heavy metals in the growth medium. 
Table 2: Metals and metalloids concentration in LB Lennox + 2 g/L glucose medium

\begin{tabular}{|c|c|}
\hline Elements & Concentration / ppm \\
\hline${ }^{7} \mathrm{Li}$ & 36.69 \\
\hline${ }^{11} \mathrm{~B}$ & 10.31 \\
\hline${ }^{24} \mathrm{Mg}$ & 204.67 \\
\hline${ }^{27} \mathrm{Al}$ & 4.77 \\
\hline${ }^{43} \mathrm{Ca}$ & 227.87 \\
\hline${ }^{53} \mathrm{Cr}$ & 74.55 \\
\hline${ }^{55} \mathrm{Mn}$ & 1.29 \\
\hline${ }^{56} \mathrm{Fe}$ & 404.57 \\
\hline${ }^{57} \mathrm{Fe}$ & 1425.00 \\
\hline${ }^{59} \mathrm{Co}$ & 0.13 \\
\hline${ }^{60} \mathrm{Ni}$ & 1.77 \\
\hline${ }^{63} \mathrm{Cu}$ & 15.57 \\
\hline${ }^{66} \mathrm{Zn}$ & 1.69 \\
\hline${ }^{69} \mathrm{Zn}$ & 0.18 \\
\hline${ }^{106} \mathrm{Cd}$ & 10.28 \\
\hline${ }^{108} \mathrm{Cd}$ & 5.85 \\
\hline${ }^{111} \mathrm{Cd}$ & 0.00 \\
\hline${ }^{137} \mathrm{Ba}$ & 0.41 \\
\hline${ }^{206} \mathrm{~Pb}$ & 0.00 \\
\hline${ }^{207} \mathrm{~Pb}$ & 0.00 \\
\hline${ }^{208} \mathrm{~Pb}$ & 0.00 \\
\hline${ }^{209} \mathrm{Bi}$ & 0.48 \\
\hline
\end{tabular}

Similar to LB Lennox medium, elevated concentrations of chromium (74.55 ppm), copper (15.57 ppm), cadmium-106 (10.28 ppm), and cadmium-108 (5.85 ppm) were detected by ICP-MS in LB Lennox $+2 \mathrm{~g} / \mathrm{L}$ glucose medium (Table 2 ). 
Table 3: Metals and metalloids concentration in LB Lennox (89 mM phosphate) medium

\begin{tabular}{cc} 
Elements & Concentration / ppm \\
\hline${ }^{7} \mathrm{Li}$ & 5.39 \\
${ }^{11} \mathrm{~B}$ & 14.61 \\
${ }^{24} \mathrm{Mg}$ & 156.47 \\
${ }^{27} \mathrm{Al}$ & 4.42 \\
${ }^{43} \mathrm{Ca}$ & 177.87 \\
${ }^{53} \mathrm{Cr}$ & 84.77 \\
${ }^{55} \mathrm{Mn}$ & 1.79 \\
${ }^{56} \mathrm{Fe}$ & 413.40 \\
${ }^{57} \mathrm{Fe}$ & 1157.00 \\
${ }^{59} \mathrm{Co}$ & 0.06 \\
${ }^{60} \mathrm{Ni}$ & 2.52 \\
${ }^{63} \mathrm{Cu}$ & 36.15 \\
${ }^{66} \mathrm{Zn}$ & 0.53 \\
${ }^{69} \mathrm{Zn}$ & 0.00 \\
${ }^{106} \mathrm{Cd}$ & 0.00 \\
${ }^{108} \mathrm{Cd}$ & 0.00 \\
${ }^{111} \mathrm{Cd}$ & 0.00 \\
${ }^{137} \mathrm{Ba}$ & 0.41 \\
${ }^{206} \mathrm{~Pb}$ & 0.00 \\
${ }^{207} \mathrm{~Pb}$ & 0.00 \\
${ }^{208} \mathrm{~Pb}$ & 0.00 \\
${ }^{209} \mathrm{Bi}$ & 0.11 \\
\hline &
\end{tabular}

ICP-MS also detected elevated concentrations of chromium (84.77 ppm) and copper (36.15 ppm) in LB Lennox medium with $89 \mathrm{mM}$ of phosphate buffer (Table 3). Non-detection of cadmium could be precipitation of the heavy metal under high ionic strength environment of the buffered medium, and subsequent removal of the precipitates through filtration prior to ICP-MS analysis. 
Table 4: Metals and metalloids concentration in LB Lennox $(89 \mathrm{mM}$ phosphate $)+6 \mathrm{~g} / \mathrm{L}$ glucose medium

\section{Elements Concentration / ppm}

\begin{tabular}{cc}
\hline${ }^{7} \mathrm{Li}$ & Not detected \\
${ }^{11} \mathrm{~B}$ & 31.34 \\
${ }^{24} \mathrm{Mg}$ & 126.17 \\
${ }^{27} \mathrm{Al}$ & 15.38 \\
${ }^{43} \mathrm{Ca}$ & 101.47 \\
${ }^{53} \mathrm{Cr}$ & 22.53 \\
${ }^{55} \mathrm{Mn}$ & 227.47 \\
${ }^{56} \mathrm{Fe}$ & 255.90 \\
${ }^{57} \mathrm{Fe}$ & 945.30 \\
${ }^{59} \mathrm{Co}$ & 0.65 \\
${ }^{60} \mathrm{Ni}$ & 3.19 \\
${ }^{63} \mathrm{Cu}$ & 46.83 \\
${ }^{66} \mathrm{Zn}$ & 0.00 \\
${ }^{69} \mathrm{Zn}$ & 0.06 \\
${ }^{106} \mathrm{Cd}$ & 0.00 \\
${ }^{108} \mathrm{Cd}$ & 0.00 \\
${ }^{111} \mathrm{Cd}$ & 1.40 \\
${ }^{137} \mathrm{Ba}$ & 0.15 \\
${ }^{206} \mathrm{~Pb}$ & 0.41 \\
${ }^{207} \mathrm{~Pb}$ & 0.22 \\
${ }^{208} \mathrm{~Pb}$ & 0.00 \\
\hline${ }^{209} \mathrm{Bi}$ & 0.62 \\
\hline
\end{tabular}

Table 4 shows the metal and metalloid concentrations in LB Lennox (89 $\mathrm{mM}$ phosphate $)+6 \mathrm{~g} / \mathrm{L}$ glucose medium. Elevated concentrations of chromium $(22.53 \mathrm{ppm})$, manganese (227.47 ppm), and copper (46.83 ppm) were detected in the growth medium, which meant that the medium would not be suitable for cultivating bacteria sensitive to toxicity effect from heavy metals. 
Table 5: Metals and metalloids concentration in formulated medium $+6 \mathrm{~g} / \mathrm{L}$ glucose medium

\begin{tabular}{|c|c|}
\hline Elements & Concentration / ppm \\
\hline${ }^{7} \mathrm{Li}$ & 0.00 \\
\hline${ }^{11} \mathrm{~B}$ & 12.62 \\
\hline${ }^{24} \mathrm{Mg}$ & 189.93 \\
\hline${ }^{27} \mathrm{Al}$ & 3.49 \\
\hline${ }^{43} \mathrm{Ca}$ & 170.63 \\
\hline${ }^{53} \mathrm{Cr}$ & 77.68 \\
\hline${ }^{55} \mathrm{Mn}$ & 1.82 \\
\hline${ }^{56} \mathrm{Fe}$ & 388.47 \\
\hline${ }^{57} \mathrm{Fe}$ & 1017.63 \\
\hline${ }^{59} \mathrm{Co}$ & 0.00 \\
\hline${ }^{60} \mathrm{Ni}$ & 2.70 \\
\hline${ }^{63} \mathrm{Cu}$ & 42.21 \\
\hline${ }^{66} \mathrm{Zn}$ & 0.89 \\
\hline${ }^{69} \mathrm{Zn}$ & 0.00 \\
\hline${ }^{106} \mathrm{Cd}$ & 17.14 \\
\hline${ }^{108} \mathrm{Cd}$ & 2.92 \\
\hline${ }^{111} \mathrm{Cd}$ & 0.00 \\
\hline${ }^{137} \mathrm{Ba}$ & 0.41 \\
\hline${ }^{206} \mathrm{~Pb}$ & 0.00 \\
\hline${ }^{207} \mathrm{~Pb}$ & 0.00 \\
\hline${ }^{208} \mathrm{~Pb}$ & 0.00 \\
\hline${ }^{209} \mathrm{Bi}$ & 0.58 \\
\hline
\end{tabular}

Table 5 reveals elevated concentrations of chromium (77.68 ppm), copper (42.21 ppm), cadmium-106 (17.14 ppm), and cadmium-108 (2.92 ppm) in formulated medium $+6 \mathrm{~g} / \mathrm{L}$ glucose. 
Table 6: Metals and metalloids concentration in Tryptic soy broth

\begin{tabular}{cc} 
Elements & Concentration / ppm \\
\hline${ }^{7} \mathrm{Li}$ & 117.39 \\
${ }^{11} \mathrm{~B}$ & 21.52 \\
${ }^{24} \mathrm{Mg}$ & 162.83 \\
${ }^{27} \mathrm{Al}$ & 9.58 \\
${ }^{43} \mathrm{Ca}$ & 195.57 \\
${ }^{53} \mathrm{Cr}$ & 64.21 \\
${ }^{55} \mathrm{Mn}$ & 1.48 \\
${ }^{56} \mathrm{Fe}$ & 325.03 \\
${ }^{57} \mathrm{Fe}$ & 1011.47 \\
${ }^{59} \mathrm{Co}$ & 0.52 \\
${ }^{60} \mathrm{Ni}$ & 1.21 \\
${ }^{63} \mathrm{Cu}$ & 30.55 \\
${ }^{66} \mathrm{Zn}$ & 3.20 \\
${ }^{69} \mathrm{Zn}$ & 0.71 \\
${ }^{106} \mathrm{Cd}$ & 6.85 \\
${ }^{108} \mathrm{Cd}$ & 8.77 \\
${ }^{111} \mathrm{Cd}$ & 0.00 \\
${ }^{137} \mathrm{Ba}$ & 1.23 \\
${ }^{206} \mathrm{~Pb}$ & 2.95 \\
${ }^{207} \mathrm{~Pb}$ & 1.43 \\
${ }^{208} \mathrm{~Pb}$ & 1.92 \\
${ }^{209} \mathrm{Bi}$ & 4.96 \\
& \\
\hline
\end{tabular}

Elevated concentrations of different heavy metals were found in Tryptic Soy Broth (Table 6). Specifically, chromium (64.21 ppm), copper (30.55 ppm), cadmium-106 (6.85 ppm), cadmium-108 (8.77 ppm), lead-206 (2.95 ppm), lead-207 (1.43 ppm), and lead-208 (1.92 ppm) were detected in the medium. 


\section{Table 7: Metals and metalloids concentration in M9 medium}

\begin{tabular}{cc} 
Elements & Concentration / ppm \\
\hline${ }^{7} \mathrm{Li}$ & 0.03 \\
${ }^{11} \mathrm{~B}$ & 0.04 \\
${ }^{24} \mathrm{Mg}$ & 0.18 \\
${ }^{27} \mathrm{Al}$ & 6.17 \\
${ }^{43} \mathrm{Ca}$ & 0.00 \\
${ }^{53} \mathrm{Cr}$ & 0.03 \\
${ }^{55} \mathrm{Mn}$ & 0.00 \\
${ }^{56} \mathrm{Fe}$ & 0.00 \\
${ }^{57} \mathrm{Fe}$ & 0.00 \\
${ }^{59} \mathrm{Co}$ & 0.00 \\
${ }^{60} \mathrm{Ni}$ & 0.01 \\
${ }^{63} \mathrm{Cu}$ & 0.00 \\
${ }^{66} \mathrm{Zn}$ & 0.00 \\
${ }^{69} \mathrm{Zn}$ & 0.00 \\
${ }^{106} \mathrm{Cd}$ & 0.00 \\
${ }^{108} \mathrm{Cd}$ & 0.00 \\
${ }^{111} \mathrm{Cd}$ & 0.00 \\
${ }^{137} \mathrm{Ba}$ & 0.00 \\
${ }^{206} \mathrm{~Pb}$ & 0.00 \\
${ }^{207} \mathrm{~Pb}$ & 0.00 \\
${ }^{208} \mathrm{~Pb}$ & 0.00 \\
${ }^{209} \mathrm{Bi}$ & 0.00 \\
\hline
\end{tabular}

Different from other growth media profiled in this study, there was no detection of heavy metals in M9 medium (Table 7). 
Table 8: Metals and metalloids concentration in M9 + $1 \mathrm{~g} / \mathrm{L}$ yeast extract medium

\begin{tabular}{cc} 
Elements & Concentration / ppm \\
\hline${ }^{7} \mathrm{Li}$ & 0.01 \\
${ }^{11} \mathrm{~B}$ & 0.00 \\
${ }^{24} \mathrm{Mg}$ & 0.30 \\
${ }^{27} \mathrm{Al}$ & 11.20 \\
${ }^{43} \mathrm{Ca}$ & 0.00 \\
${ }^{53} \mathrm{Cr}$ & 0.09 \\
${ }^{55} \mathrm{Mn}$ & 0.59 \\
${ }^{56} \mathrm{Fe}$ & 0.06 \\
${ }^{57} \mathrm{Fe}$ & 0.00 \\
${ }^{59} \mathrm{Co}$ & 0.00 \\
${ }^{60} \mathrm{Ni}$ & 0.01 \\
${ }^{63} \mathrm{Cu}$ & 0.00 \\
${ }^{66} \mathrm{Zn}$ & 0.00 \\
${ }^{69} \mathrm{Zn}$ & 0.00 \\
${ }^{106} \mathrm{Cd}$ & 0.00 \\
${ }^{108} \mathrm{Cd}$ & 0.00 \\
${ }^{111} \mathrm{Cd}$ & 0.00 \\
${ }^{137} \mathrm{Ba}$ & 0.00 \\
${ }^{206} \mathrm{~Pb}$ & 0.00 \\
${ }^{207} \mathrm{~Pb}$ & 0.00 \\
${ }^{208} \mathrm{~Pb}$ & 0.00 \\
${ }^{209} \mathrm{Bi}$ & 0.00 \\
\hline
\end{tabular}

Similar to the case for M9 medium, there was also no detection of heavy metals in M9 $+1 \mathrm{~g} / \mathrm{L}$ yeast extract medium.

\section{Conclusions}

Trace elements such as metals and metalloids play important roles in biochemistry and cellular metabolism. Thus, their provision in growth medium is critical for ensuring good growth performance from microorganisms. This study sought to investigate the trace metal element concentrations in a variety of common microbiological media ranging from minimal salts to complex chemically undefined medium. Results reveal unexpected elevated concentrations of heavy metals in many complex undefined media such as LB Lennox and Tryptic Soy Broth. Heavy metals of concern are principally chromium, copper, cadmium, and lead. Concentrations of heavy metals in the tens of parts per million meant that the media could only be used in cultivation of bacteria bearing some resistance to heavy metal toxicity effect. 
This then limits the utility of the growth media to cultivation of environmental microbes as compared to laboratory domesticated species. On the contrary, no heavy metals were detected in minimal salts medium such as M9 medium. Overall, the results of this study highlight the importance of gaining understanding of the metal and metalloid concentrations in different growth media both from the perspective of quality control purposes as well as understanding growth performance of particular microbe in the medium.

\section{Conflicts of interest}

The author declares no conflicts of interest.

\section{Funding}

The author thank the National University of Singapore for financial support.

\section{References}

1 Costa, O. Y. A. et al. Impact of Different Trace Elements on the Growth and Proteome of Two Strains of Granulicella, Class "Acidobacteriia". Frontiers in Microbiology 11, doi:10.3389/fmicb.2020.01227 (2020).

2 Glass, J. \& Orphan, V. Trace Metal Requirements for Microbial Enzymes Involved in the Production and Consumption of Methane and Nitrous Oxide. Frontiers in Microbiology 3, doi:10.3389/fmicb.2012.00061 (2012).

3 Maret, W. Zinc Biochemistry: From a Single Zinc Enzyme to a Key Element of Life. Advances in Nutrition 4, 82-91, doi:10.3945/an.112.003038 (2013).

4 McCall, K. A., Huang, C.-c. \& Fierke, C. A. Function and Mechanism of Zinc Metalloenzymes. The Journal of Nutrition 130, 1437S-1446S, doi:10.1093/jn/130.5.1437S (2000).

5 Thiele, D. J. Integrating Trace Element Metabolism from the Cell to the Whole Organism. The Journal of Nutrition 133, 1579S-1580S, doi:10.1093/jn/133.5.1579S (2003).

6 McCall, K. A. \& Fierke, C. A. Colorimetric and Fluorimetric Assays to Quantitate Micromolar Concentrations of Transition Metals. Analytical Biochemistry 284, 307315, doi:https://doi.org/10.1006/abio.2000.4706 (2000).

7 Hofstetter, J. C. et al. Quantitative colorimetric paper analytical devices based on radial distance measurements for aqueous metal determination. Analyst 143, 30853090, doi:10.1039/C8AN00632F (2018).

8 Laur, N. et al. ICP-MS trace element analysis in serum and whole blood. PLOS ONE 15, e0233357, doi:10.1371/journal.pone.0233357 (2020).

9 Bressy, F. C., Brito, G. B., Barbosa, I. S., Teixeira, L. S. G. \& Korn, M. G. A. Determination of trace element concentrations in tomato samples at different stages of maturation by ICP OES and ICP-MS following microwave-assisted digestion. Microchemical Journal 109, 145-149, doi:https://doi.org/10.1016/j.microc.2012.03.010 (2013).

10 Väisänen, A., Laatikainen, P., Ilander, A. \& Renvall, S. Determination of mineral and trace element concentrations in pine needles by ICP-OES: evaluation of different 
bioRxiv preprint doi: https://doi.org/10.1101/2020.09.25.313221; this version posted September 25, 2020. The copyright holder for this preprint (which was not certified by peer review) is the author/funder, who has granted bioRxiv a license to display the preprint in perpetuity. It is made available under aCC-BY 4.0 International license.

sample pre-treatment methods. International Journal of Environmental Analytical Chemistry 88, 1005-1016, doi:10.1080/03067310802308483 (2008). 